\title{
Editorial
}

\section{New Editors Join Genome Research}

The field of genomics has grown and changed dramatically over the last several years, with extensive data sets, new methods, and novel ideas. In an effort to keep up with and look ahead to further advances in this whole-genome era, Genome Research has just added two additional scientific Editors to our staff. We do this in an effort to make sure we can best assess all the manuscripts we are now seeing and to continue to broaden our scope. It is always our goal to encapsulate all the elements involved in this scientific arena-one that encompasses scientific endeavors for defining biological function; developing bioinformatics tools; analyzing genes, proteins, and systems on a large-scale; creating novel technology; and much more.

I hope you will join me in welcoming Dr. Evan Eichler and Dr. William Pavan to our existing list of Editors: Dr. Aravinda Chakravarti, Dr. Richard Gibbs, Dr. Eric Green, and Dr. Richard Myers.

Dr. Evan Eichler is based in the Department of Genetics at Case Western Reserve University in Cleveland, Ohio. The research goals in Dr. Eichler's laboratory center on analyzing human gene duplication and DNA transposition for understanding genomic instability as it relates to evolution, disease, and diversity. His laboratory is specifically interested in determining the mechanisms underlying duplication events, in de-

Article and publication are at http://www.genome.org/cgi/doi/10.1101/ gr.572802. tecting and characterizing regions of rapid evolution, and in developing computational methods to identify and determine features of highly homologous duplications in primates and other vertebrates.

Dr. William Pavan is located in the Genetic Disease Research Branch at the National Human Genome Research Institute in Bethesda, Maryland. Dr. Pavan's work focuses on understanding the mechanisms underlying neural crest development and how this relates to disease development. His laboratory uses the mouse as a model system and combines the use of mouse mutants and functional genomics techniques to address questions relating to cell migration, cell differentiation, and mechanisms for disease.

Finally, please note another addition to the journal: Our new Assistant Editor, Dr. Maureen Megonigal, joins us from the Children's Hospital of Philadelphia. Her background is diverse and has involved studies of molecular and genetic changes in myeloid lymphoid leukemia and investigations of DNA damage and cell death in yeast.

I am delighted to have Dr. Eichler, Dr. Pavan, and Dr. Megonigal associated with Genome Research. All of the Editors (new and old) look forward to seeing you at upcoming meetings and to considering your interesting work for publication in the journal.

-Laurie Goodman 


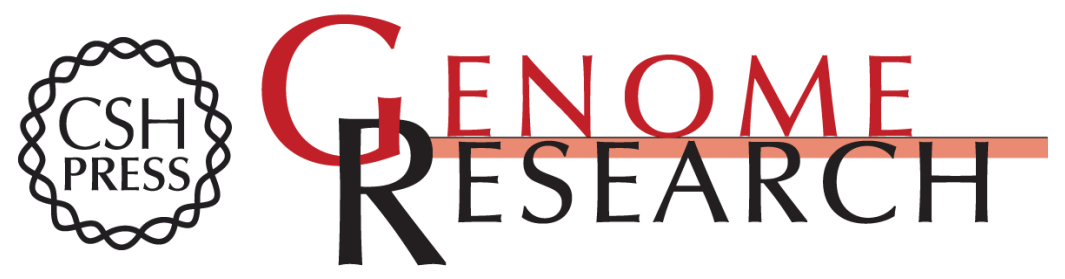

\section{New Editors Join Genome Research}

Laurie Goodman

Genome Res. 2002 12: 1151

Access the most recent version at doi:10.1101/gr.572802

\section{License}

Email Alerting Receive free email alerts when new articles cite this article - sign up in the box at the Service top right corner of the article or click here.

\section{Affordable, Accurate Sequencing.}

To subscribe to Genome Research go to:

https://genome.cshlp.org/subscriptions 